\title{
HUBUNGAN KEPATUHAN PENGGUNAAN ALAT PELINDUNG DIRI MASKER TERHADAP KEJADIAN INFEKSI SALURAN PERNAFASAN AKUT (ISPA) PADA PEKERJA MEBEL DI UNIT PENGAMPLASAN KAYU CV BELLA-BELLA KABUPATEN JEPARA
}

*Achmad Sururi, **Yunani, **Achmad Syaifudin

Stikes Karya Husada Semarang

Email: achmadsururi05@gmail.com

\begin{abstract}
ABSTRAK
Latar Belakang : Industri furniture yang merupakan industri padat karya dengan 4 juta orang yang mengandalkan industri ini sebagai sumber penghasilan, salah satu masalah yang dihasilkan dengan adanya kegiatan industri adalah pencemaran udara. Penyakit yang dapat diakibatkan oleh adanya pencemaran udara salah satunya yaitu infeksi saluran pernapasan akut, paparan atau risiko bahaya yang ada di tempat kerja tidak selalu dapat dihindari, oleh karena itu langkah yang paling aman adalah pekerja harus memakai APD. Tujuan : Mengetahui Hubungan Kepatuhan Penggunaan Alat Pelindung Diri Masker Terhadap Kejadian Infeksi Saluran Pernafasan Akut (ISPA) Pada Pekerja Mebel di Unit Pengamplasan Kayu CV Bella-bella Kabupaten Jepara. Metode : Penelitian ini merupakan penelitian kuantitatif dengan pendekatan analitik korelasional. Untuk mengetahui hubungan antara kepatuhan penggunaan alat pelindung diri masker terhadap kejadian ISPA pada pekerja mebel di unit pengamplasan kayu CV Bella-Bella Kabupaten Jepara Hasil : Saat dilakukan tabulasi silang dan pengujian didapatkan data bahwa 1 cells $(25,0 \%)$ mempunyai nilai expected count kurang dari 5 sehingga tidak memenuhi syarat dilakukan uji Chi square. Maka dalam penelitian ini dilakukan uji fisher exact, hasil uji fisher P value $=0,002$. Karena nilai $\mathrm{p}$ value lebih kecil dari 0,05, ada hubungan kepatuhan penggunaan APD masker terhadap kejadian ISPA pada pekerja mebel di unit pengamplasan kayu CV bella-bella Kabupaten Jepara. Kesimpulan : Ada hubungan kepatuhan penggunaan APD masker terhadap kejadian ISPA pada pekerja mebel di unit pengamplasan kayu CV bella- bella Kabupaten Jepara.

Kata kunci : Kepatuhan penggunaan APD masker, Kejadian ISPA
\end{abstract}

\section{THE CORELATION BETWEEN PERSONAL PROTECTIVE EQUIPMENT AND THE USE OF MASK TO THE WORKERS' ACUTE RESPIRATORY INFECTIONS (ARI) IN UNIT} SANDING WOOD FURNITURE CV BELLA-BELLA JEPARA.

\begin{abstract}
ABSTRACK
Background: the furniture industry was a labor-intensive industry with 4 million people who rely on this industry as a source of income, one of the problems generated by the industrial activity was air pollution. A disease that could be caused by the air pollution was acute respiratory infection, the exposure or hazard in the workplace could not always be avoided, therefore the safest step was that workers should wear PPE. Objective: To determine The Corelation Between Personal Protective Equipment And The Use Of Mask To The Workers' Acute Respiratory Infections (ARI) In Unit Sanding Wood Furniture CV Bella-Bella Jepara. Methods: This research was a correlational quantitative analytic approach. Result: The researcher conducted a cross tabulation and test data obtained that 1 cells (25.0\%) have expected count value was less than 5 so, it was not eligible Chi square test. So in this research, fisher exact test, the test results Fisher $P$ value $=0.002$. Because the $p$ value less than 0.05, there was a compliance with PPE use masks relation to the incidence of respiratory infection in workers of furniture in wood sanding unit $\mathrm{CV}$ bella-bella Jepara regency. Conclusion: There was a correlation Between Personal Protective Equipment And The Use Of Mask To The Workers' Acute Respiratory Infections (ARI) In Unit Sanding Wood Furniture CV Bella-Bella Jepara
\end{abstract}

Keywords: PPE mask, ARI 


\section{PENDAHULUAN}

Pertumbuhan ekonomi Indonesia diperkirakan pada tahun 2015 bisa tumbuh sekitar $5,8 \%$. Untuk bisa tumbuh lebih tinggi, diperlukan pertumbuhan ekspor produk komoditi Indonesia yang lebih cepat dibandingkan pertumbuhan import barang ke Indonesia. Industri furniture (mebel) yang merupakan industri padat karya, dengan 4 juta orang yang mengandalkan industri ini sebagai sumber penghasilan, berperan menyumbangkan penghasilan devisa dari ekspor sebesar US\$1,779 miliar di tahun 2013. Jumlah tersebut 50\% dari ekspor kayu dan produk dari kayu Indonesia. Keterampilan para pengrajin dalam menciptakan disain produk mebel dan kerajinan tangan memperlihatkan ciri khas budaya daerah masing-masing (Kemenko, 2014).

Salah satu masalah yang dihasilkan dengan adanya kegiatan industri adalah pencemaran udara. Pencemaran udara adalah terkontaminasinya udara, baik dalam ruangan (indoor) maupun luar ruangan (outdoor), dengan agen kimia, fisik, atau biologi yang telah merubah karakteristik alami dari atmosfer (WHO, 2011). Hal ini banyak disebabkan oleh asap pembakaran rumah tangga, proses industri, kendaraan bermotor, dan kebakaran hutan.

Penyakit yang dapat diakibatkan oleh adanya pencemaran udara salah satunya yaitu infeksi saluran pernapasan akut (ISPA). Penyakit ini bisa terjadi karena adanya asap rokok, asap pembakaran dirumah tangga, gas buang sarana transportasi dan industri, kebakaran hutan dan lain-lain. (Depkes, 2009).

Jumlah tenaga kerja industri furniture/mebel kayu Kabupaten Jepara pada tahun 20082012, bahwa pada tahun 2008 sebnayak 50.668 tenaga kerja, meningkat pada tahun 2009 sebanyak 51.934 tenaga kerja, meningkat pada tahun 2010 sebanyak 52.443 tenaga kerja, meningkat pada tahun 2011 sebanyak 53.334 tenaga kerja, meningkat lagi pada tahun 2012 sebanyak 54.400 tenaga kerja.

Kejadian penyakit ISPA di Jepara juga masih cukup tinggi, dimana dari data Profil Dinas Kesehatan Jepara Pada Bulan Januari sampai Novemberr 2010 jumlah pneumonia sebanyak 4990 orang, dan pneumonia berat sebanyak 27 orang. Wilayah puskesmas Keling merupakan wilayah dengan angka pneumonia tertinggi dari seluruh puskesmas yang ada di Jepara. Jumlah pneumonia di wilayah puskesmas Keling sebanyak 823 orang, dan pneumonia berat sebanyak 17 orang (Profil Dinas Kesehatan Jepara 2010). 
Tenaga kerja sebagai sumber daya manusia, perlu mendapat perhatian khusus baik kemampuan, keselamatan, maupun kesehatan kerjanya. Aktivitas dalam suatu industri, paparan atau risiko bahaya yang ada di tempat kerja tidak selalu dapat dihindari, oleh karena itu langkah yang paling aman adalah memakai APD.

Berdasarkan penelitian yang dilakukan oleh Khumaidah (2009) pada pekerja mebel PT. Kota Jati Furnindo Kabupaten Jepara terdapat hubungan yang signifikan ( $<<0,05)$ antara gangguan fungsi paru dengan kadar debu terhirup, masa kerja, penggunaan APD (Alat Pelindung Diri), Hubungan Antara Karakteristik Pekerja Dan Pemakaian Alat Pelindung Pernapasan (Masker) Dengan Kapasitas Fungsi Paru Penelitian yang dilakukan oleh Kandung, R.(2013) Pada Pekerja Wanita Bagian Pengampelasan di Industri Mebel "X" Wonogiri juga mengatakan ada hubungan antara pemakaian masker dengan kapasitas fungsi paru dengan nilai $(\mathrm{p}<0,05)$.

\section{METODE PENELITIAN}

Jenis penelitian ini merupakan penelitian kuantitatif dengan pendekatan analitik korelasional. Desain penelitian menggunakan rancangan cross sectional, dimana variabel independen (kepatuhan pengunaan APD masker), dan variabel dependen (kejadian ISPA), dikumpulkan dalam waktu yang bersamaan. Penelitian ini ingin mengetahui hubungan antara kepatuhan penggunaan alat pelindung diri masker terhadap kejadian ISPA pada pekerja mebel di unit pengamplasan kayu CV Bella-Bella Kabupaten Jepara.

\section{HASIL DAN PEMBAHASAN}

1. Analisa Univariat

Tabel 1. Distribusi Responden berdasarkan tingkat kepatuhan penggunaan APD masker pada Pekerja Amplas di CV. Bella Bella Tahun 2015

\begin{tabular}{lcc}
\hline $\begin{array}{c}\text { Kepatuhan } \\
\text { penggunaan APD } \\
\text { masker }\end{array}$ & Frekuensi & Persentase \\
\hline Patuh & 20 & 57,1 \\
Tidak patuh & 15 & 43,9 \\
\hline Jumlah & 35 & 100 \\
\hline
\end{tabular}

Berdasarkan tabel 4.1 dapat diketahui bahwa kepatuhan penggunaan APD masker sebagian besar responden patuh menggunakan APD masker sebanyak 20 responden 
(57.1\%), sedangkan responden yang tidak patuh menggunakan APD masker sebanyak 15 responden $(42.9 \%)$.

Tabel 2. Distribusi Responden berdasarkan tingkat kejadian ISPA pada Pekerja Amplas di CV. Bella Bella Tahun 2015

\begin{tabular}{lcc}
\hline \multicolumn{1}{c}{ Kejadian ISPA } & Frekuensi & Persentase \\
\hline Tidak ISPA & 10 & 28,6 \\
Mengalami ISPA & 25 & 71,4 \\
\hline Jumlah & 35 & 100 \\
\hline
\end{tabular}

Berdasarkan tabel 2 dapat diketahui bahwa kejadian ISPA sebagian besar responden mengalami ISPA sebanyak 25 responden $(71.4 \%)$, sedangkan yang tidak ISPA sebanyak 10 responden $(28.6 \%)$.

2. Analisa Bivariat.

Hubungan Kepatuhan Penggunaan Alat Pelindung Diri Masker Terhadap Kejadian Infeksi Saluran Pernafasan Akut (ISPA) Pada Pekerja Mebel di Unit Pengamplasan Kayu CV Bella-bella Kabupaten Jepara di uji dengan menggunakan uji Chi square. Saat dilakukan tabulasi silang dan pengujian didapatkan data bahwa 1 cells $(25,0 \%)$ mempunyai nilai expected count kurang dari 5 sehingga tidak memenuhi syarat dilakukan uji Chi square. Maka dalam penelitian ini dilakukan uji fisher exact, dengan hasil seperti tabel 3 sebagai berikut:

Tabel 3 Hubungan Kepatuhan Penggunaan APD Masker Terhadap Kejadian ISPA Pada Pekerja Mebel di Unit Pengamplasan Kayu CV Bella-bella Kabupaten Jepara Tahun 2015

\begin{tabular}{lccccccc}
\hline Kepatuhan & \multicolumn{3}{c}{ Kejadian ISPA } & Total & $\%$ & P \\
\cline { 2 - 5 } $\begin{array}{c}\text { penggunaan } \\
\text { APD masker }\end{array}$ & Tidak ISPA & $\%$ & ISPA & $\%$ & & & value \\
\hline Patuh & 10 & 50,0 & 10 & 50,0 & 20 & 100 & \multirow{2}{*}{0,002} \\
Tidak patuh & 0 & 0,0 & 15 & 100 & 15 & 100 & \\
\hline Jumlah & 10 & 26,6 & 25 & 71,4 & 35 & 100 & \\
\hline
\end{tabular}

Berdasarkan tabel 3 menunjukkan hasil analisis kepatuhan penggunaan APD masker terhadap kejadian ISPA diperoleh bahwa 20 responden yang patuh menggunakan APD 
masker sebanyak 10 (28.6\%) tidak mengalami ISPA, dan dari 20 responden yang patuh menggunakan ADP masker sebnayak 10 (28.6\%) mengalami ISPA, dan dari 15 responden yan tidak patuh menggunakan APD masker sebanyak $0(0 \%)$ tidak mengalami ISPA, dan sebanyak 15 responden yang tidak patuh menggunaka APD masker sebanyak 15 (42.9\%) mengalami ISPA. Hasil uji fisher $\mathrm{P}$ value $=0,002$. Karena nilai $\mathrm{p}$ value lebih kecil dari 0,05 maka dapat disimpulkan ada hubungan yang signifikan antara Hubungan Kepatuhan Penggunaan APD Masker Terhadap Kejadian ISPA Pada Pekerja Mebel di Unit Pengamplasan Kayu CV Bella-bella Kabupaten Jepara.

Hubungan Kepatuhan Penggunaan APD Masker Terhadap Kejadian ISPA Pada Pekerja Mebel di Unit Pengamplasan Kayu CV Bella-bella Kabupaten Jepara.

Berdasarkan hasil penelitian menunjukkan dari 15 responden yang tidak patuh menggunakan APD masker sebanyak 15 responden (42.9\%) terkena ISPA, yang di buktikan dengan pekerja sering mengalami flu, demam, batuk, radang tenggorokan, dan sesak nafas pada kurun waktu 3 bulan terakhir, jadi penelitian ini terdapat hubungan yang signifikan antara Hubungan Kepatuhan Penggunaan APD Masker Terhadap Kejadian ISPA Pada Pekerja Mebel di Unit Pengamplasan Kayu CV Bella-bella Kabupaten Jepara (P value $=0,002)$.

Penelitian ini sejalan dengan penelitian yang dilakukan oleh (Khumaidah. 2009) yang berjudul Analisis Faktor-Faktor yang Berhubungan Dengan Gangguan Fungsi Paru Pada Pekerja Mebel PT. Kota Jati Furnindo Desa Suwawal Kecamatan Mlonggo Kabupaten Jepara, dari 6 pekerja dengan tidak menggunakan APD terdapat 6 responden (100\%) yang mengalami gangguan pada paru ( $\mathrm{P}$ value $=0,002$ ), nilai X2 $=6,656$ dan nilai Odd Ratio $=8,571$ (95\% CI = 0,907-80,993). Hal ini menunjukkan bahwa pekerja yang tidak menggunakanan APD mempunyai risiko dapat terjadi gangguan paru sebesar 8,5 kali dibanding pekerja yang menggunakan APD.

\section{KESIMPULAN}

1. Kepatuhan menggunakan APD masker sebagihan besar 20 responden (57.1\%) menggunakan APD masker.

2. Agka kejadian ISPA sebanyak 25 responden (71.4\%) 
3. Pekerja yang tidak patuh menggunaka APD masker sebanyak 15 responden (42.9\%) mengalami ISPA.

4. Ada hubungan yang signifikan antara hubungan kepatuhan penggunaan APD masker terhadap kejadian ISPA pada pekerja mebel di unit pengamplasan kayu CV Bella-Bella Kabupaten Jepara $(P$ value $=0,002)$.

\section{SARAN}

1. Bagi Perusahaan CV Bella-bella Jepara.

Menyediakan ventilasi yang cukup untuk menjamin suhu yang nyaman, sirkulasi udara segar di ruang kerja, masuknya cahaya matahari ke ruang kerja, dan menerapkan wet methods (cara basah), yaitu cara yang digunakan untuk mengendalikan dispersi debu yang mengotori lingkungan kerja dengan mengunakan air atau bahan-bahan yang bersifat basah lainya,

2. Bagi karyawan CV Bella-bella Jepara.

Menggunakan masker setiap berada di lingkungan industri pengamplasan secara kontinu dan masker sekali pakai, serta memeriksakan kesehatan secara periodik dan teratur untuk memantau kondisi kesehatan fisik para pekerja.

3. Bagi peneliti selanjutnya.

Diharapkan bagi penelitian selanjutnya untuk melakukan penelitian tentang faktor yang berbeda dari penelitian ini, misalkan Kepatuhan Penggunaan APD masker terhadap kejadian ISPA pada pekerja mebel di unit penyemprotan dan finishing.

\section{DAFTAR PUSTAKA}

Alsagaf H dr, Mangunegoro.2004. Nilai Normal Faal paru orang Indonesia pada Usia Sekolah dan Pekerja Dewasa Berdasarkan Rekomendasi American Thoracic Society (ATS) 1987: Indonesia Preumobil Project, Airlangga University Press, Surabaya.

Asrini. 2013, Gambaran Penggunaan Alat Pelindung Diri Dan Gangguan Kesehatan Pekerja Industri Meubel Di Kecamatan Tolangohula Kabupaten Gorontalo, [jurnal]. Program Studi Kesehatan Masyarakat Universitas Negeri Gorontalo.

Departemen Kesehatan Republik Indonesia Direktorat Jenderal Pengendalian Penyakit dan Penyehatan Lingkungan. Pedoman pengendalian penyakit infeksi saluran pernaasan akut. Jakarta: 2009 , 2009. Profil Kesehatan Indonesia Jakarta: Depkes RI. P.39-40.

2007. Pedoman Pengobatan Dasar di Puskesmas. Direktorat Jendral Bina Farmasi Komunitas dan Klinik. Direktorat Jenderal Bina Kefarmasian dan Alat Kesehatan. Florencia, Dinda, A. 2013, Pengaruh Pajanan Debu Urea Terhadap Infeksi Saluran Pernafasan Akut (ISPA) Pada Pekerja Di Unit Pengantongan Pupuk Urea (PPU) PT. Pupuk Sriwidjaja Palembang Tahun 2013, [Skripsi]. Fakultas Kesehatan Masyarakat Universitas Sriwijaya.

Halim, Fitria. 2012, Hubungan Faktor Lingkungan Fisik Dengan Kejadian Infeksi Saluran Pernapasan Akut (ISPA) Pada Pekerja Di Industri Mebel, Dukuh Tukrejo, Desa Bondo, Kecamatan Bangsri, Kabupaten Jepara, Propinsi Jawa Tengah 2012, [Skripsi]. Program Sarjana Kesehatan Masyarakat Universitas Indonesia 
Irawan Edy Putra http://www.ekon.go.id/berita/pdf/kemenko- perekonomian.973.pdf diakses tanggal 9 Januari 2015.

Kandung, R, P, B. 2013 Hubungan Antara Karakteristik Pekerja Dan Pemakaian Alat Pelindung Pernapasan (Masker) Dengan Kapasitas Fungsi Paru Pada Pekerja Wanita Bagian Pengampelasan Di Industri Mebel " $X$ " Wonogiri, jurnal Kesehatan Masyarakat, Universitas Diponegoro Semarang.

Khumaidah. 2009, Analisis Faktor-Faktor yang Berhubungan Dengan Gangguan Fungsi Paru Pada Pekerja Mebel PT. Kota Jati Furnindo Desa Suwawal Kecamatan Mlonggo Kabupaten Jepara, [Tesis]. Program Pasca Sarjana Universitas Diponogoro Semarang. Misnadiarly. (2008). Penyakit Infeksi Saluran Napas Pneumonia Pada Anak Balita, Orang Dewasa, Usia Lanjut. Edisi Pertama. Jakarta: Pustaka Obor Popular.

Ngastiyah. (2005). Perawatan Anak Sakit edisi 2. Jakarta: EGC. Nofidahanum. 2011, Pengaruh Faktor Lingkungan, Riwayat

Pekerjaan, Kebiasaan Merokok Dan Penggunaan Alat Pelindung Diri Terhadap Gejala Gangguan Saluran Pernafasan Pada Pekerja Industri Meubel Di Kota Banda Aceh Tahun 2011, [Tesis]. Program Studi S2 Ilmu Kesehatan Masyarakat Fakultas Kesehatan Masyarakat Universitas Sumatera Utara Medan.

Noor, N (2006) Pengantar Epidemiologi Penyakit Menular. Jakarta: Rineka Cipta.

Notoatmodjo S, (2009). Pengantar Pendidikan Kesehatan Dan Ilmu Perilaku. Jakarta : PT RINEKA.

-----------, (2003). Ilmu kesehatan masyarakat: Prinsip-prinsip Dasar.Cetakan ke-2. Jakarta: Rineka Cipta.

---, (2010). Ilmu kesehatan masyarakat (Prinsip-prinsip dasar kesehatan). Jakarta: PT. Rineka Cipta.

---------, (2012). Metodologi penelitian kesehatan. Jakarta: Rineka Cipta, 2012.

Peraturan Menteri Tenaga Kerja Dan Transmigrasi Republik Indonesia Nomor PER.08/MEN/VII/2010 Tentang Alat Pelindung Diri.

Permata P.E, Octrani. 2014. Analisis Permintaan Tenaga Kerja Industri Kecil Menengah (IKM) Furniture/Mebel Kayu di Kabupaten Jepara, [Skripsi]. Fakultas Ekonomika Dan Bisnis Universitas Diponegoro Semarang.

Pope, C. 2003. Respiratory Health and PM 10 Pollution. AM.Rev. Respiartory Desease. New York.

Putranto, A., 2007. Pajanan Debu Kayu (PM10) dan Gejala Penyakit Saluran Pernafasan pada Pekerja Mebel Sektor Informal di Kota Pontianak Kalimantan Barat, Thesis, PS-UI.

Saryono. (2011). Metodologi penelitian kesehatan: penuntun praktis bagi pemula. Yogyakarta: Mitra Cendikia Press.

Soepardi, Efiaty Arsyad, dkk, 2007, Buku Ajar Ilmu Kesehatan Telinga Hidung Tenggorok Kepala \& Leher, ( Edisi Keenam), Jakarta: Penerbit Fakultas Kedokteran Universitas Indonesia.

Sukardi. 2004. Metodologi Penelitian Pendidikan Kompetensi dan Praktiknya. Jakarta: Bumi Aksara.

Suleman, H, U. 2012. Hubungan Faktor Lingkungan Rumah Dengan Kejadian Infeksi Saluran Pernapasan Akut (ISPA) Pada Balita Di Wilayah Kerja Puskesmas Kabila Kabupaten Bone Bolango Tahun 2012, [Skripsi]. Peminatan Kesehatan Lingkungan, Jurusan Kesehatan Masyarakat, Fakultas Ilmu Kesehatan dan Keolahragaan, Universitas Negeri Gorontalo. 
Syair, Abdul. (2009). Faktor Resiko Kejadian Infeksi Saluran Pernapasan Akut (ISPA) pada Balita. from http//syair79.wordpress.com. Diakses pada tanggal 17 Maret 2012.

Undang-undang Repoblik Indonesia No.1 tahun 1970 Tentang Keselamatan Kerja. Ketentuan Alat Pelindung Diri.

WHO. 2011. Air pollution. Available from http://www.who.int/topics/air_pollution/en/

Yunus, F. 2006. Dampak Debu Industri Pada Pekerja, FKUI Bagian Pulmonologi FKUI/ Unit Paru RSUP Persahabatan, Cermin Dunia Kedokteran Respir, Jakarta (http://www.cermin dunia kedokteran.com).

Yusnabeti., Ririn Arminsih Wulandari \& Ruth Luciana. 2010. PM10 dan Infeksi Saluran Pernapasan Akut Pada Pekerja Industri Mebel, Departemen Kesehatan Lingkungan, Fakultas Kesehatan Masyarakat, Universitas Indonesia. 